\title{
Feather corticosterone in Northern Bald Ibis Geronticus eremita: a stable matrix over time able to predict reproductive success
}

\author{
Laura Monclús $^{1,4}\left(\mathbb{0} \cdot\right.$ Oriol Tallo-Parra $^{2} \cdot$ Anais Carbajal $^{1} \cdot$ Miguel Angel Quevedo $^{3} \cdot$ Manel Lopez-Bejar $^{1}$
}

Received: 31 May 2019 / Revised: 14 November 2019 / Accepted: 16 December 2019 / Published online: 29 January 2020

(c) The Author(s) 2020

\begin{abstract}
Measuring corticosterone concentrations in feathers (FCC) has been increasingly used as an integrated index of bird's response to stressors, offering valuable insights into subsequent carry-over effects. However, it is still unclear to what extent corticosterone levels deposited in feathers during the moulting period relate to individual physiology in high-energetic demanding situations. In addition, the stability and repeatability of FCC over the same feather generation and across successive generations are still unresolved questions. In this study, we assessed FCC in 24 captive Northern Bald Ibis, Geronticus eremita. We sampled body feathers on three occasions during two consecutive years (2015-2016) to explore within-individual stability of FCC in feathers grown during the same generation and test whether FCC was repeatable or varied between two consecutive generations. Then, we explored whether FCC (a) was associated with individual health status, (b) correlated with previous reproductive success and (c) was related to future reproductive success. Results showed high stability of FCC among feathers of the same generation, while FCC differed between successive generations. We also observed that FCC, age and health status were negatively associated with subsequent reproductive success the following season, while no association was found with previous reproductive success. Overall, our study supports the use of feathers as a stable measure of corticosterone over the same feather replacement generation and emphasizes the usefulness of FCC as a biomarker of subsequent reproductive success.
\end{abstract}

Keywords Birds $\cdot$ Chronic stress $\cdot$ Glucocorticoids $\cdot$ Non-invasive $\cdot$ Biomarker

\section{Zusammenfassung}

Feder-Corticosteron beim Waldrapp Geronticus eremita: Eine zeitlich stabile Matrix ermöglicht Voraussagen über den Reproduktionserfolg

Das Messen der Corticosteronkonzentrationen in Federn (engl. feather corticosterone concentration, FCC) ist ein immer stärker genutzter, integrierter Index für die Stressreaktion eines Vogels. Dies ermöglicht wertvolle Einblicke in nachfolgende Carry-Over-Effekte. Jedoch ist immer noch unklar, in welchem Ausmaß der Corticosteronspiegel, der während der Mauserzeit in den Federn erreicht wird, mit der individuellen Physiologie in energetisch höchst anspruchsvollen Situationen zusammenhängt. Weiterhin ist die Stabilität und Messwiederholbarkeit der FCC innerhalb einer und zwischen aufeinanderfolgenden Federgenerationen noch ungeklärt. In dieser Studie haben wir die FCC von 24 in Gefangenschaft gehaltenen Waldrappen Geronticus eremita untersucht. Wir sammelten Körperfedern zu drei verschiedenen Zeitpunkten in zwei aufeinanderfolgenden Jahren (2015-2016), um die individuenspezifische FCC-Stabilität in Federn der gleichen Generation zu untersuchen und um zu testen, ob die FCC-Messungen zwischen zwei aufeinanderfolgenden Jahren

Communicated by L. Fusani.

Electronic supplementary material The online version of this article (https://doi.org/10.1007/s10336-019-01741-z) contains supplementary material, which is available to authorized users.

Laura Monclús

laura.monclus@ntnu.no

Extended author information available on the last page of the article 
wiederholbar waren oder Unterschiede aufwiesen. Daraufhin untersuchten wir, ob FCC (a) mit dem Gesundheitszustand des Individuums, (b) dem vorherigen und (c) dem zukünftigen Reproduktionserfolg korrelierte. Die Ergebnisse zeigten eine hohe Stabilität der FCC innerhalb der gleichen Federgeneration, während sich die FCC zwischen aufeinanderfolgenden Generationen unterschieden. Wir konnten ebenfalls feststellen, dass FCC, Alter und Gesundheitszustand negativ mit dem nachfolgenden Reproduktionserfolg der nächsten Saison korrelierten, während kein Zusammenhang zum vorherigen Reproduktionserfolg gefunden werden konnte. Zusammenfassend befürwortet unsere Studie die Nutzung von Federn als stabile Messung des Corticosterons innerhalb einer Federgeneration und bekräftigt die Nützlichkeit von FCC als Biomarker für den nachfolgenden Reproduktionserfolg.

\section{Introduction}

Under some stress stimulus, corticosterone (CORT; the main glucocorticoid in birds) is released in blood circulation by the hypothalamic-pituitary-adrenal (HPA) axis which enables the animal to direct its normal activity to an "emergency" state (Wingfield et al. 1998) and prioritize its resources towards self-maintenance (Jenni et al. 2000) (the so-called stress response). Despite this adaptive mechanism, the functioning of the HPA axis is altered when the stressor(s) is persistent or highly frequent resulting in elevated CORT levels in an extended period which can have detrimental consequences for the animal's health, survival and reproduction (Romero et al. 2009; Wingfield and Sapolsky 2003).

Blood has been by far the most preferred matrix to quantify the stress response although it is considered an invasive matrix (Müller et al. 2007). As a consequence, minimally or non-invasive matrices, such as faeces (Möstl et al. 2005) and more recently feathers (Bortolotti et al. 2008; Romero and Fairhurst 2016), have emerged as alternatives. Unlike blood or faeces, feathers represent a unique matrix because they provide an integrative, long-term and retrospective picture of physiology over time. They incorporate CORT which was released during the whole period of feather growth, thus reflecting the HPA axis activity during this limited period of time which can extent from weeks to months (Bortolotti et al. 2009; Jenni-Eiermann et al. 2015; Aharon-Rotman et al. 2015). This matrix is easy to collect and does not require special conditions for transport or storage. Additionally, it has been shown that small daily variations in baseline CORT levels do not affect global feather CORT concentrations (FCC) (Bortolotti et al. 2008; Fairhurst et al. 2013), which is similar to what it occurs in mammalian hair (Tallo-Parra et al. 2016).

As a relatively new technique, feathers still present some methodological issues that need to be addressed for reliable interpretation of data (Romero and Fairhurst 2016). For instance, stability and repeatability of CORT in feathers is of special concern. It is vital that FCC are similar among feathers grown during the same moulting period, which represents the same feather generation, and that this measure is stable in feathers over time. Researchers are often uncertain of the time gap between feather growth and feather sampling and analysis. Given that physical degradation of feather material occurs over time, this may affect FCC (Romero and Fairhurst 2016). Studying the stability of FCC across the same feather generation is, therefore, crucial for data interpretation. Another unresolved question is whether within-individual differences in FCC persist or vary across two different feather generations responding to internal or environmental conditions. This is a relatively understudied concept with mixed results reported. For example, great FCC variation was observed between successive years in greater snow geese (Chen caerulescens atlantica) and in common eiders (Somateria millissima) in relation to climate conditions (Legagneux et al. 2013), while high inter-annual repeatability was reported in house sparrows (Passer domesticus) highlighting the influence of individual quality in FCC (Aharon-Rotman et al. 2015).

Despite the potential methodological limitations, the use of FCC in literature has grown exponentially since its very beginning (Bortolotti et al. 2008). Several authors have applied this matrix in an ecological context, i.e., relating FCC to reproductive parameters, sexual selection, nutrition (Crossin et al. 2013) as well as studying the effects of stressful or challenging environments such as pollution [i.e., organic pollutants (Monclús et al. 2019)]. More recently, researchers have used FCC as a biomarker of carry-over effects relating FCC to subsequent migratory (Harms et al. 2015), survival (Koren et al. 2012; Monclús et al. 2017) and breeding performances (Harms et al. 2015; Will et al. 2014; Ramos et al. 2018), and as a biomarker of allostatic overload (Johns et al. 2018). However, the reported relationships are complex, and it remains unclear whether FCC can reflect and predict individual physiology in front of high energetically demanding situations such as reproduction (Fairhurst et al. 2017; Harris et al. 2017).

The present study aimed to evaluate the usefulness of FCC as a biomarker of fitness in an endangered bird species, the Northern Bald Ibis Geronticus eremita (hereafter called ibis). This long-lived species, classified as Critically Endangered (BirdLife International 2016), has suffered a big decline in numbers over the past decades due to 
different anthropogenic disturbances (Boehm and Bowden 2010; Serra et al. 2015; BirdLife International 2016). So far, several captive breeding and reintroduction programs have been established around Europe (e.g., Waldrapp team in Austria, Germany, Italy and Proyecto Eremita in Southern Spain). However, high euthanasia rate is described in captive ibis due to chronic ulcerative dermatitis that appear to be related to feather picking and self-mutilation compulsive disorders (Quevedo 2009). Despite its critically conservation status, very few authors have investigated CORT levels in this species (Dorn et al. 2014; PuehringerSturmayr et al. 2018).

We divided the present study into two parts. The first part was designed as a methodological approach with two objectives. First, (i) we evaluated within-individual stability of FCC in feathers of the same generation by comparing FCC among feathers sampled on the same day and feathers sampled on different months. If FCC is indeed a robust and reliable measure, we should find equal hormonal levels among the different feather pools collected. Second, (ii) we investigated whether within-individual differences in FCC persist in the subsequent feather generation and thus the potential of this method to be used as an indicator of individual state. The second part of this study addressed two biological questions: (iii) whether FCC related to reproductive success and (iv) whether ibis with chronic diseases presented differences in FCC and reproductive parameters compared to "healthy" birds. Specifically, we evaluated whether FCC: (a) was associated with individual health status, (b) correlated with previous reproductive success, and (c) was related to future reproductive success.

\section{Materials and methods}

\section{Animals, housing conditions, diet and management}

We used a mixed-sex flock of 24 captive ibis (mean age 18.5 years; range $4-30$ years; 14 males, 10 females). The group was held at Zoobotánico Jerez (Cádiz, Spain) and was part of the Proyecto Eremita set in Southern Spain. All animals were born in captivity and kept under the same conditions in an outdoor flight aviary $(11 \mathrm{~m}$ width $\times 15 \mathrm{~m}$ length $\times 8 \mathrm{~m}$ height), with natural vegetation, water ad libitum, subjected to natural photoperiod and temperature, and fed with the same diet (mixture of minced heart of beef, chicken, carrots, pellets for insectivorous birds, multivitamins and carotenes).

Ibis are monomorphic and gregarious with a clear social hierarchy (Cramp 1998). They generally reach sexual maturity around 3 years (Cramp 1998; del Hoyo et al. 1992). Breeding activity starts in March (Sorato and Kotrschal 2006) and eggs are usually laid between March and May, although some flexibility in the timing has been described due to climate conditions (del Hoyo et al. 1992). Both parents participate in building the nest, incubating the eggs and raising the chicks. Average clutch size is 3 eggs and hatching is asynchronous within intervals from 1 to 3 days (Sorato and Kotrschal 2006). Nestlings are fully fledged after 42-50 days (own observations). Extramarital copulatory behaviour is registered during the breeding season and breeding pairs can change in the following year (Cramp 1998). Ibis used in this study were free to pair and breed. In 2016, as part of the reintroduction programme Proyecto Eremita, eggs were removed from their parents, artificially incubated and hand reared by foster parents to increase hatching ratio and chick survival.

\section{Study design}

Three samplings were carried out encompassing two consecutive feather generations (Fig. 1). From the first feather generation, we sampled 11 ibis in October 2014 (Sampling A) and 22 in March 2015 (Sampling B). From the second feather generation, we sampled 22 ibis in November 2015 (Sampling C). In this latter case, we simultaneously collected a second pool of feathers from the same anatomical region in 18 individuals. Note that individuals sampled were different for each Sampling case (see Table ESM 1 in Electronic Supplementary Material). Each sampling procedure achieved different objectives. Samplings A and B were used to evaluate within-individual FCC stability between feathers sampled at different times during the same feather generation $(n=11)$. Samplings B and C were used to assess within-individual FCC variation between two consecutive feather generations and to explore the relationship with health and breeding success $(n=22)$. Finally, Sampling C was used to test within-individual FCC stability between pools of feathers sampled simultaneously $(n=18)$.

\section{Feather and data collection}

In total, we analysed 75 samples (ESM 1). In all cases, we pulled feathers during routine medical examinations and stored them in paper envelopes at room temperature. We sampled interscapular feathers as their collection was judged to have less impact on flight dynamics. These body feathers are replaced each year during the moulting period, from August to October (Gill 2007; Hardy et al. 2006). Medical data and reproductive success were recorded during all the study. Of the 24 ibis, 2 (9.1\%) presented ulcerative chronic dermatitis and 5 (22.7\%) presented chronic disabilities such as flight disabilities $(n=2)$, partial beak amputation $(n=2)$ and microphthalmia $(n=1)$. 


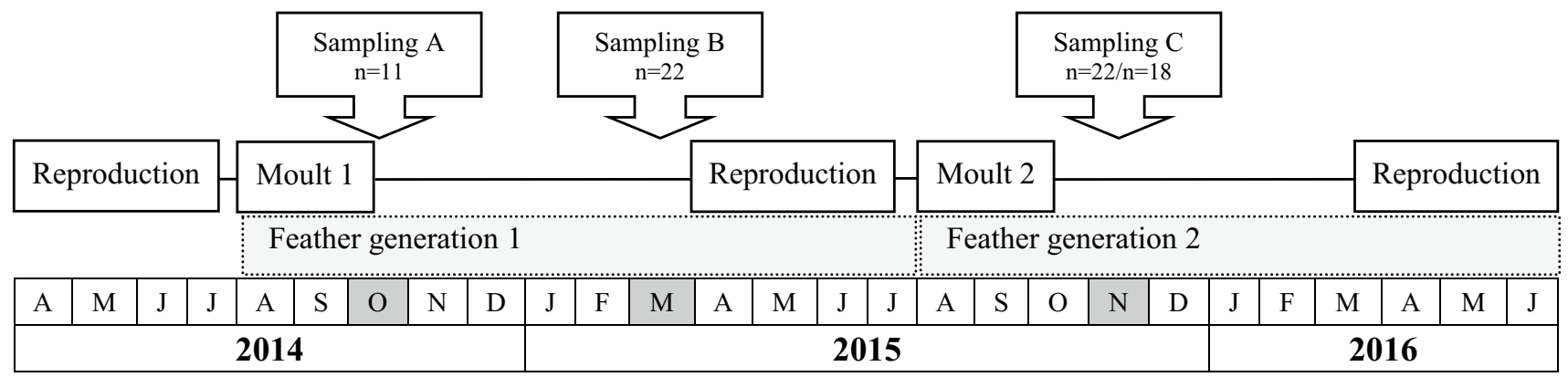

Fig. 1 Time frame of feather sampling and data recording. Northern Bald Ibis were sampled in three occasions: Sampling A (October 2014); Sampling B (March 2015); and Sampling C (November 2015)

\section{Feather steroid extraction}

In this study, CORT concentrations were normalized per length (mm) and feather mass (mg) was controlled to eliminate any potential confounding effects on FCC as recommended (Lattin et al. 2011; Crossin et al. 2013; Fairhurst et al. 2013; Patterson et al. 2015). Three to five interscapular feathers were analysed per individual to obtain the same longitude range $(21.9 \mathrm{~cm} \pm 1.5 \mathrm{~cm})$ and a minimum mass of $50 \mathrm{mg}$ was required. In all cases, the two measures (pg mm${ }^{-1}$ and $\mathrm{pg} \mathrm{mg}^{-1}$ ) were highly correlated (Pearson correlation test; $r=0.84, P<0.01$ ).

For FCC extraction, a modified protocol described by Bortolotti et al. (2008) was followed with modifications based on Monclús et al. (2017). Briefly, from each sample, the calamus was removed since it has a different growth rate than the rest of the feather. Then, the selected feathers were minced together with scissors into pieces of $<3 \mathrm{~mm}^{2}$. Methanol (10 mL; Scharlab, S.L., Sentmenat, Spain) was added and samples were vortexed (Vortex Mixer S0200-230 V-EU; Labnet International Inc, NJ, USA) for $30 \mathrm{~min}$ at room temperature before they were shaken (G24 Environmental Incubator Shaker; New Brunswick Scientific Co. Inc., Edison, NJ, USA) for $18 \mathrm{~h}$ at $32{ }^{\circ} \mathrm{C}$ for steroid extraction. The methanol was then separated from the feather material using vacuum filtration. The obtained methanol extract was dried in an oven (Kendro Laboratory Products, Langenselbold, Germany) at $37{ }^{\circ} \mathrm{C}$. Once the methanol was completely evaporated, extract residues were reconstituted in $250 \mu \mathrm{L}$ buffer solution provided by the enzyme immunoassay kit (Corticosterone ELISA kit; Neogen ${ }^{\circledR}$ Corporation, Ayr, UK) and shaken for $30 \mathrm{~s}$. Samples were then immediately stored at $-20{ }^{\circ} \mathrm{C}$ until analyses.

\section{Steroid analysis and validation tests}

We determined FCC using competitive CORT enzyme immunoassay kits (Neogen ${ }^{\circledR}$ Corporation, Ayr, UK) and encompassing two consecutive feather generations. Reproductive data was recorded for 2014, 2015 and 2016

validated the immunoassay following the essential criteria of precision, accuracy, specificity and sensitivity (Mccallister and Smith 1996; Sink et al. 2008). Extracts from 20 ibis were pooled and used for validation. A mean $( \pm S D)$ intraassay coefficient of variation $(\mathrm{CV})$ of $5.74( \pm 3.78) \%$ and an inter-assay CV of $12.53( \pm 4.20) \%$ were obtained. All samples were above the detection limit $\left(0.556 \mathrm{pg} \mathrm{mm}^{-1}\right.$ feather). Pooled samples showed parallel displacement with the standard curve (standard curve: $y=0.092 x-0.477, R^{2}=99 \%$; pool feather samples: $\left.y=0.060 x+0.305, R^{2}=92 \%\right)$. The linearity of dilution showed a $R^{2}$ of $98 \%$ and a mean percentage error of $-11.09 \pm 11.29 \%$. The average recovery percentage from spike-and-recovery test was $107.86 \pm 13.77 \%$. In accordance to the manufacturers' instructions, the cross reactivity of the kit was as follows: $38 \%$ deoxycorticosterone; $19 \%$ 6-hydroxycorticosterone; $5.1 \%$ progesterone; $2.7 \%$ tetrahydrocorticosterone; $1.5 \%$ prednisolone; $1.1 \%$ cortisol. Steroids with cross reactivity $<0.9 \%$ are not presented.

\section{Statistical analysis}

All analyses were performed using R version 3.2.2 (R-project, R Development Core Team, University of Auckland, New Zealand). For all models, the standardized residues were assessed to meet normality and homogeneity of variance and, when they were not normally distributed, $\log 10$ transformations were applied. The level of significance was set at $\alpha=0.05$ throughout the study.

To test within-individual variations on FCC, we used mixed-effects models. First, we tested whether the two pools of feathers sampled at the same time from the same individual showed similar FCC ( $n=18$; Sampling C). Second, we tested whether individual FCC varied among months belonging to the same feather generation $(n=22$; Sampling A and B). In both cases, we conducted FCC (expressed as pg CORT $\mathrm{mm}^{-1}$ feather) as the dependent variable and individual identity as random effect to account for repeated samples on the same individuals. The intra-class correlation 
coefficient (ICC), expressed as $d^{2} /\left(d^{2}+\sigma^{2}\right)$, was used as a measure of repeatability. It was calculated based on: the variance explained by the model (between-individual variance) $(d)$; and the variance explained by the residual (withinindividual variance) ( $\sigma$ ) (Nakagawa and Schielzeth 2010). The ICC ranges from 0 to 1 with values close to 1 meaning that most of the variance is explained by between-individual differences.

We then determined whether FCC were consistent between two consecutive feather generations ( $n=22$; Samplings B and C). We used mixed-effects model with normal distribution and identity function. FCC was set as the dependent variable and period (Sampling B/Sampling C), sex and age were placed as fixed factors. Individual identity was used as random effect to account for repeated samples. A second mixed-effects model was performed to test for differences in FCC as a function of health and previous reproductive success. Given that the goal was to explore the relationship with physiological parameters, the different periods (Sampling B/Sampling C) as well as individual identity were placed as random effects. Sex and age were placed as fixed factors. For the previous reproductive success, recorded at 2014 and 2015 (Fig. 1), different variables were recorded: (1) breeding success (three levels: successful paired-successful breeding, successful paired-failed breeding, and failed paired-failed breeding); (2) reproductive success (two levels: successful paired-successful breeding, failed paired or failed breeding); (3) fecundity (number of eggs); and (4) fledging success (number of young that successfully fledged). We used different models to test each variable separately. Individuals with flight pathologies $(n=2)$ were eliminated as these birds were not able to arrive at the upper nests. Regarding health, we tested separately in two models: (1) general health (two levels: healthy vs. unhealthy with the latter including chronic disabilities and skin disease) and (2) pathological alterations (three levels: healthy birds, birds with chronic disabilities, birds with skin diseases).

A generalised linear mixed model, with binomial distribution and logit link function, was performed to analyse the relation of FCC and subsequent reproductive success, recorded in 2015 and 2016 (Fig. 1). In the case of 2016, eggs were collected and incubated artificially. Therefore, fecundity and fledging success variables were excluded from the analyses and we only distinguished reproductive success (two levels: successfully paired vs. failed paired). Reproductive success (yes/no) was placed as the dependent variable and the explanatory variables included FCC, age, sex and health (different models for general health and for pathological alterations, see above). Individual identity and periods (Sampling B/Sampling C) were placed as random effects.

In all cases, the initial model contained all the main effects and all the possible interactions. The models were evaluated and ranked using the Akaike's Information
Criterion corrected for small sample size $\left(\mathrm{AIC}_{c}\right)$ (Burnham and Anderson 2002). The four most supported models and the null model are reported in $\mathrm{AIC}_{c}$ tables (ESM 2, 3 and 4). All models with $\mathrm{AIC}_{c}$ scores within 2 points of the lowest scoring model $\left(\Delta \mathrm{AIC}_{c}<2\right)$ were considered within the candidate model selection. We used package 'nlme' and 'Ime4' (R Core Team 2015).

\section{Results}

\section{Within-individual stability of FCC}

The two pools of feathers collected in Sampling C showed similar FCC (Table 1). The ICC of the model was 0.82 (with $d^{2}=2.29$ and $\sigma^{2}=1.08$ ) showing low within-individual variation. When comparing FCC between Samplings A and B, no statistical difference was found (Table 1) and ICC also indicated low variation (ICC $=0.77$ with $d^{2}=2.12$ and $\sigma^{2}=1.16$ ).

\section{Repeatability of FCC across consecutive feather generations}

The best-supported model explaining differences in FCC between feather generations included sex and period (ESM 2). We found that FCC significantly decreased from Sampling B to Sampling C (Table 2, Fig. 2a). In addition, individual FCC greatly varied between the two feather generations (Fig. 2b). Sex did not influence FCC $(P>0.05)$.

\section{Relationship with health status and reproduction}

\section{Health status and previous reproductive success}

The best-supported model explaining FCC variation only included sex (ESM 3) and this was not significant (all $P>0.05)$. In fact, the null model produced $\Delta \mathrm{AIC}_{c}<2$ from the best-supported model. Thus, neither health, reproduction nor age were explanatory variables for FCC.

\section{Subsequent reproductive success}

The most parsimonious model explaining differences on subsequent reproductive success included health, FCC and age (ESM 4). The amount of CORT accumulated in feathers grown during the moulting period was negatively associated with the following reproductive success (Table 3), with successful birds displaying lower FCC than birds which failed to reproduce (Fig. 3a). Age and health also influenced subsequent reproductive success (Table 3), with unhealthy and older birds being associated with reproductive failure 
Table 1 Comparison of corticosterone levels among feathers sampled during the same feather generation in Northern Bald Ibis (Geronticus eremita)
Table 2 Comparison of corticosterone levels between two feather generations in Northern Bald Ibis (Geronticus eremita)

\begin{tabular}{|c|c|c|c|c|c|c|}
\hline & \multirow[t]{2}{*}{$n$} & \multicolumn{2}{|c|}{ pg CORT $\mathrm{mm}^{-1}$ feather } & \multicolumn{3}{|l|}{ Statistic output } \\
\hline & & Mean \pm SD & Range & Estimate $\pm \mathrm{SE}$ & $t$ value & $P$ value \\
\hline Sampling C-Pool 1 & 18 & $7.42 \pm 2.05$ & [2.61-10.97] & & & \\
\hline Sampling C-Pool 2 & 18 & $7.99 \pm 2.90$ & [3.61-12.36] & $-0.26 \pm 0.36$ & -0.72 & 0.48 \\
\hline Sampling A & 11 & $9.76 \pm 1.97$ & [6.81-13.11] & & & \\
\hline Sampling B & 11 & $9.01 \pm 2.78$ & {$[4.75-13.52]$} & $-0.71 \pm 0.94$ & -0.75 & 0.46 \\
\hline
\end{tabular}

Two pools of samples were collected in Sampling C (pool 1 and pool 2) reflecting feather generation 2. Two pools of samples were collected at different times (Sampling A and B), both reflecting feather generation 1 . Mean $\pm \mathrm{SD}$, range and statistic output are shown

\begin{tabular}{|c|c|c|c|c|c|c|}
\hline \multirow[t]{2}{*}{ Sex } & \multirow[t]{2}{*}{$n$} & \multicolumn{2}{|c|}{ pg CORT $\mathrm{mm}^{-1}$ feather } & \multicolumn{3}{|l|}{ Statistic output } \\
\hline & & Mean \pm SD & Range & Estimate $\pm \mathrm{SE}$ & $t$ value & $P$ value \\
\hline \multicolumn{7}{|l|}{ Sampling B } \\
\hline Males & 12 & $8.90 \pm 1.79$ & [5.63-10.88] & & & \\
\hline Females & 10 & $8.06 \pm 3.12$ & {$[4.75-13.52]$} & & & \\
\hline All & 22 & $8.14 \pm 2.23$ & {$[4.75-13.52]$} & $-1.49 \pm 0.62$ & -2.44 & 0.02 \\
\hline \multicolumn{7}{|c|}{ Sampling C } \\
\hline Males & 12 & $7.38 \pm 2.18$ & {$[2.53-10.62]$} & & & \\
\hline Females & 10 & $6.35 \pm 2.91$ & [2.61-11.08] & & & \\
\hline All & 22 & $6.89 \pm 2.46$ & [2.53-11.08] & $1.10 \pm 0.84$ & 1.32 & 0.21 \\
\hline
\end{tabular}

Note that Sampling B refers to feathers sampled in March 2015 (Feather generation 1) and sampling C to feathers sampled in November 2015 (Feather generation 2). Mean \pm SD, range and statistic output are shown
(Fig. 3b, c). The second-best model with reasonable support ( $<2 \Delta \mathrm{AIC}_{c}$; ESM 4) included health, FCC, age and sex. In this case, the averaged parameter estimates also showed that FCC, age and health were significantly associated with subsequent reproductive success (all $P<0.001$ ), while sex was non-significant $(P=0.33)$. When health status was classified in three groups (healthy, chronic disabilities and skin disease), candidate models were similar than healthy-unhealthy classification (ESM 4). In this case, health was non-significant (all $P>0.05$ ).

\section{Discussion}

\section{Within-individual stability of FCC}

Consistent FCC were observed between the two pools of feathers sampled at the same time from the same individuals. Close agreement in FCC was previously reported in different raptor species between two opposite primary flight feathers (P5) (Strong et al. 2015) and between adjacent secondary flight feathers (S1 and S2) (Lattin et al. 2011), although these types of feathers may have an asynchronous moult which can last over 2 years (Rohwer et al. 2009). Instead, body feathers grow during a limited and more synchronized period of time, after the breeding season and preceding winter stressors and migration (Gill 2007; Hardy et al. 2006); therefore, they appear to provide more time-specific and controlled information on the HPA axis activity (Monclús et al. 2017). The small mass of body feathers especially in small bird species may limit their use, since FCC are significantly overestimated when feather mass is below a critical threshold (Berk et al. 2016; Lattin et al. 2011). To counteract this effect, we pooled 3-5 interscapular feathers to increase sample mass. Our results confirm that pooling body feathers is a consistent method for the assessment of CORT levels. In addition, this method allows standardization of the amount of feather material across samples, which reduces the effects of factors such as asynchrony in moulting (Romero and Fairhurst 2016) and poor feather quality (Aharon-Rotman et al. 2015). Notwithstanding, it is worth mentioning that the use of feather pools may also dilute single feather variations related to stress factors and thus mask potential differences. This should be further studied in future experiments.

Our results also showed stability of FCC between feathers from the same feather generation collected at two different timepoints 6 months apart. These results suggest that CORT levels remain fixed in feathers for 6 months after the end of vascularization, complementing the limited amount of literature available on CORT stability over time (Romero 


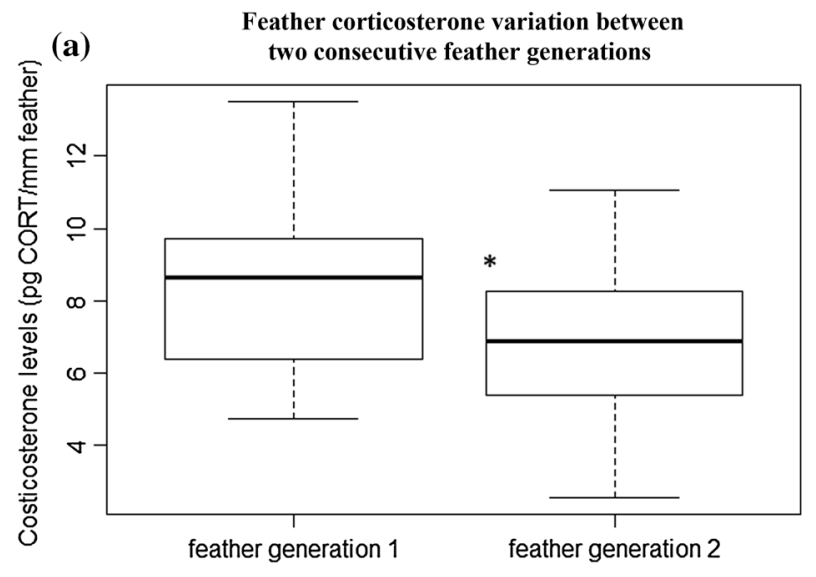

(b)

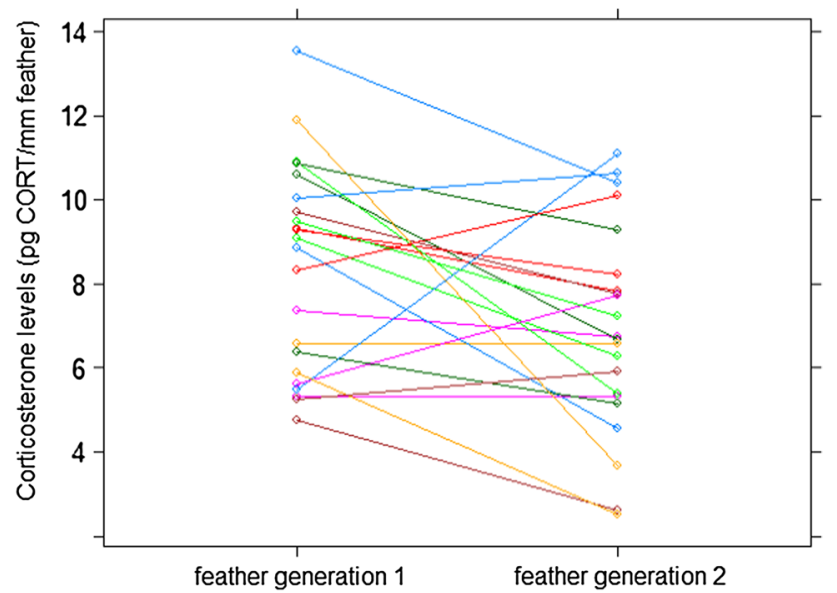

Fig. 2 a Global and $\mathbf{b}$ individual differences of feather corticosterone values (pg CORT/mm feather) between two consecutive feather generations in Northern Bald Ibis $(n=22)$. Feather generation 1 refers to corticosterone levels obtained from feathers of Sampling B (reflecting moult 1) and feather generation 2 refers to corticosterone levels obtained from feathers of Sampling $C$ (reflecting moult 2). Asterisk (*) indicates significant differences $(P<0.05)$

and Fairhurst 2016). Previous studies (Bortolotti et al. 2009; Fairhurst et al. 2015) have shown no evidence of CORT degradation among long-time series of feathers collected from museum specimens. However, the fact that these studies sampled different individuals and used feathers from different years could allow external factors interfere with the results. By exploring CORT levels between feathers grown at the same time but collected at different times, we provide evidence that FCC is a stable metric of long-term CORT levels within individuals over the same feather generation.

\section{Variation of FCC across periods and relationship with health and reproduction}

FCC significantly varied between the two consecutive feather generations analysed and showed individual variation, suggesting that birds with high FCC the first year do not necessarily show high levels the following year (Fig. 2b). We could not relate this variation to previous reproductive success nor individual health status. We suggest that FCC could rather be related to external factors, as shown in the study of Legagneux et al. (2013). The ibis in this study were kept under captive conditions with available food resources. Albeit, other external factors could have affected their physiology, for instance cold temperature. This species is very sensitive to weather changes and they can adjust their migration and reproductive behaviour depending on temperatures (del Hoyo et al. 1992), which in turn could affect their stress status and CORT secretion. In addition, pair building at the start of the reproductive season can enhance stress in ibis, and pairs can change year to year (Puehringer-Sturmayr et al. 2018). In this study, we found a relationship between FCC and subsequent reproductive success measured as successful paired—failed paired (see below).

The relationship between increasing FCC and subsequent reproductive failure the following season (Fig. 3a) is consistent with previous studies in which females of house sparrow (Ouyang et al. 2011) and European starlings (Sturnus vulgaris) (Cyr and Romero 2007) with low plasma CORT levels showed high subsequent reproductive output. Experimentally, it has been shown that elevated CORT levels suppress reproductive behaviour (reviewed in Wingfield and Sapolsky 2003). However, recent work (Pérez et al. 2016)

Table 3 Model-averaged parameter estimates and associated standard deviation, $z$ - and $P$ value for the variables contained in the best-supported model explaining success of subsequent reproduction in Northern Bald Ibis (Geronticus eremita) $(n=22)$

\begin{tabular}{|c|c|c|c|}
\hline Variable & Estimate $\pm \mathrm{SE}$ & $z$ value & $P$ \\
\hline Intercept & $-44.54 \pm 9.56 \mathrm{e}-04$ & $-434,451$ & $<0.001$ \\
\hline FCC & $8.53 \pm 9.68 \mathrm{e}-04$ & 8811 & $<0.001$ \\
\hline Age & $14.48 \pm 1.08 \mathrm{e}-03$ & 13,788 & $<0.001$ \\
\hline Unhealthy & $24.67 \pm 9.52 \mathrm{e}-04$ & 259,206 & $<0.001$ \\
\hline Random effects & \multicolumn{2}{|r|}{ Variance } & SD \\
\hline Period & \multicolumn{2}{|r|}{6.73} & 2.59 \\
\hline ID & \multicolumn{2}{|r|}{$1.51 \mathrm{e}+05$} & $3.87 e+02$ \\
\hline
\end{tabular}


Factors influencing subsequent reproductive success

(a)

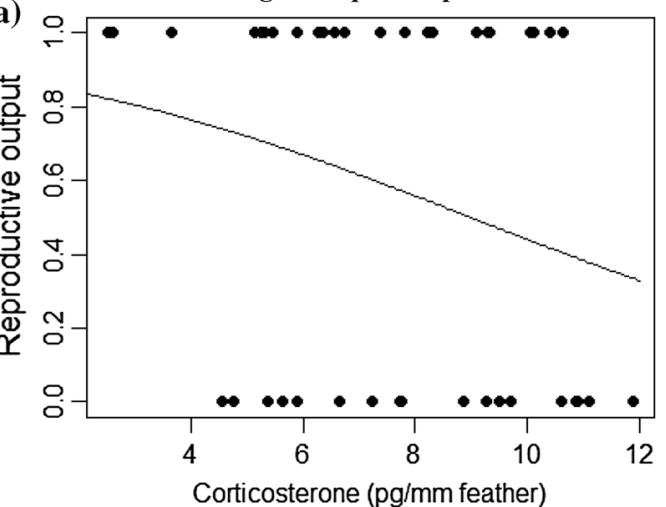

(b)

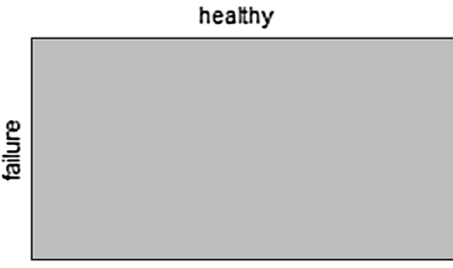

unhealthy

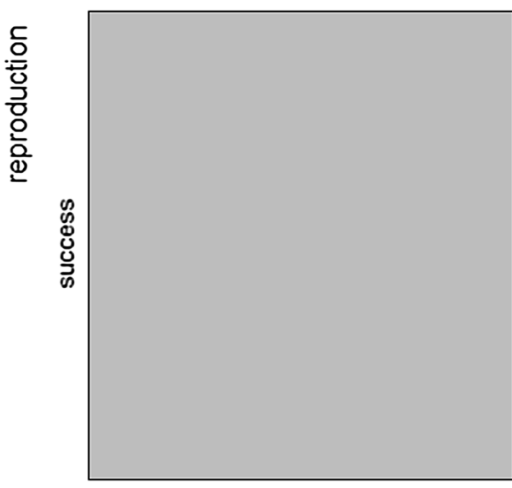

Health status

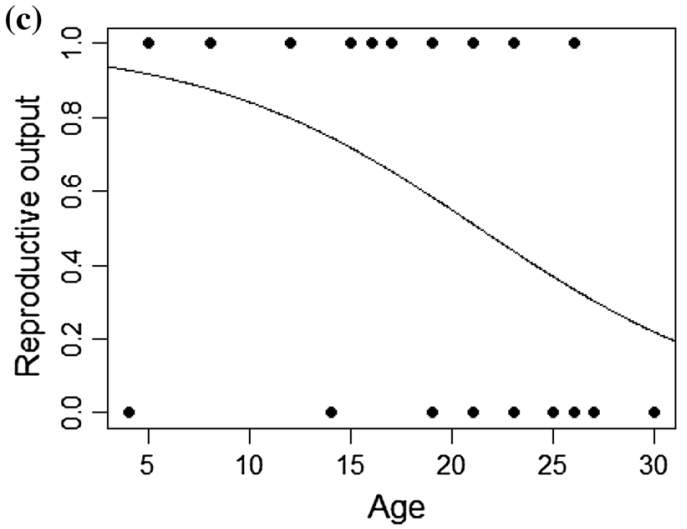

Fig. 3 Relationships between reproductive output in the subsequent breeding season and a levels of corticosterone deposited in feathers grown during the previous autumn season (pg CORT $\mathrm{mm}^{-1}$ feather); b health status; and c age, in Northern Bald Ibis $(n=22)$. In graphs a and $\mathbf{c}$ lines represent the significant logistic regression model with 1 meaning successful reproduction and 0 meaning failure reproduction reported an inverse relationship and stated that high CORT levels prepare individuals for reproductive investment. In fact, the direction of the relationship between CORT and successful reproduction may depend on environmental conditions. While under predictable environment, birds with low CORT responses have greater fitness, birds with high CORT levels breed most successfully under unpredictable or changing environment (Cockrem 2013). In this line and given that the studied ibis were kept under stable conditions, we hypothesized a negative relationship between FCC and subsequent reproductive performance. As expected, birds with low FCC succeed in their breeding, while birds with a long-term increase of FCC failed to breed the next reproductive season. However, and in agreement with a previous study (Pérez et al. 2016), we did not find any relationship between FCC and past reproductive performance; birds that fail to breed do not necessarily show an increase of the stress response in the following months.

Additionally, no association was found between FCC and chronic diseases or disabilities. This could possibly be explained by habituation or acclimation of birds to the adverse situation (Bonier et al. 2009). In our study, unhealthy birds presented skin diseases or other type of physical disabilities (see "Feather and data collection" section). It is plausible that under captive conditions and after some time, ibis with physical disabilities were able to adapt to new circumstances without presenting any HPA alteration. Experimentally, this hypothesis was proven in captive great tits (Parus major) (Cockrem and Silverin 2002), captive American kestrels (Falco sparverius) (Love et al. 2003) and free-living eastern bluebirds (Sialia sialis) (Lynn et al. 2010), that under repeated stress stimulus they first showed an increase of CORT levels that progressively decreased over time. On the other hand, we found that unhealthy birds showed worse reproductive success the following breeding season (Fig. 3b). Thus, despite having no effect on the HPA axis activity, the presence of chronic disabilities or diseases appear to affect the reproduction in captive ibis. Given the strong social hierarchy of ibis and that the mating phase is particularly stressful for this species, low-ranked individuals may have more difficulties in pairing and breeding successfully (Sorato and Kotrschal 2006). In this situation, those birds that arrive at the reproductive season chronically stressed (high FCC) or those with chronic physical disabilities may have more difficulties to breed. However, this situation may change between consecutive years, at least for birds with high FCC given that their levels may vary yearly.

Lastly, no FCC differences were found among ages and sex. These findings corroborate previous research by Sorato and Kotrschal (2006) and may be explained by the sexual monomorphic and symmetrical social structure of ibis. Although some previous studies in ibis showed sex-differences (Dorn et al. 2014), they measured CORT metabolites and thus it is not 
comparable to our results. In fact, studies performed on feathers of several other bird species also reported no sex-related differences (Carbajal et al. 2014; Koren et al. 2012; Monclús et al. 2017; Strong et al. 2015). Regarding age, similarities in FCC have been described in raptor species between immature, subadult and adult individuals (Monclús et al. 2017; Strong et al. 2015). Conversely, immature ibis were reported to show higher CORT levels compared to adults, probably reflecting a HPA response to the low-ranking position of these individuals in social hierarchy (Sorato and Kotrschal 2006). In the present study, the age of the individuals ranged from 4 to 30 years and therefore, we could not account for differences between immature and adult individuals. However, when studying parameters affecting future reproduction, we observed that the reproductive success declined in older birds (Fig. 3c), representing an important parameter for breeding performance as suggested in the literature (Blas et al. 2009; Sergio et al. 2011; LópezJiménez et al. 2016).

\section{Conclusions}

We showed that FCC exhibits high stability across a single feather generation regardless of the feather sampling timepoint, which evidences the usefulness of body feathers as a stable metric. In addition, within-individual variation in CORT levels was observed between two consecutive years. Birds showing high FCC one year do not necessarily show high levels the following year. Although we could not determinate the cause for high FCC, we provided evidence for the utility of FCC as a biomarker of future reproductive success, which is of special interest for the management of this species. Increases in energetic challenges or long-lasting stressful conditions may ultimately have consequences on the following reproductive season, particularly in pairing, and this can be predicted by FCC measured in body feathers. Due to the critically endangered status of ibis and the already great effort performed in developing reintroduction programs, we highly recommend further research focused on this issue and on elucidating the causes of high FCC.

Acknowledgements Authors gratefully acknowledge the staff from ZooBotánico de Jerez for providing all the samples and data that allowed carrying out the present study; Isabelle Russell for the English language revision of the manuscript; and Fundación Tatiana Pérez de Guzmán el Bueno (Madrid, Spain) that financially supported through a pre-doctoral fellowship to Monclús L.

Funding Open access funding provided by NTNU Norwegian University of Science and Technology (incl St. Olavs Hospital - Trondheim University Hospital).

\section{Compliance with ethical standards}

Conflict of interest The authors declare that they have no conflict of interest.
Open Access This article is licensed under a Creative Commons Attribution 4.0 International License, which permits use, sharing, adaptation, distribution and reproduction in any medium or format, as long as you give appropriate credit to the original author(s) and the source, provide a link to the Creative Commons licence, and indicate if changes were made. The images or other third party material in this article are included in the article's Creative Commons licence, unless indicated otherwise in a credit line to the material. If material is not included in the article's Creative Commons licence and your intended use is not permitted by statutory regulation or exceeds the permitted use, you will need to obtain permission directly from the copyright holder. To view a copy of this licence, visit http://creativecommons.org/licenses/by/4.0/.

\section{References}

Aharon-Rotman Y, Buchanan KL, Klaassen M, William WA (2015) An experimental examination of interindividual variation in feather corticosterone content in the House Sparrow, Passer domesticus in southeast Australia. Gen Comp Endocrinol 244:93-100. https ://doi.org/10.1016/j.ygcen.2015.12.010

Berk S, McGettrick JR, Hansen WK, Breuner CW (2016) Methodological considerations for measuring glucocorticoid metabolites in feathers. Conserv Physiol 4(1):cow020. https://doi.org/10.1093/ conphys/cow020

BirdLife International (2016) Geronticus eremita. The IUCN Red List of Threatened Species 2016:e.T22697488A993616442. https:// doi.org/10.2305/IUCN.UK.2016-3.RLTS.T22697488A93616 442.en

Blas J, Sergio F, Hiraldo F (2009) Age-related improvement in reproductive performance in a long-lived raptor: a cross-sectional and longitudinal study. Ecography (Cop.) 32:647-657. https://doi.org /10.1111/j.1600-0587.2008.05700.x

Boehm C, Bowden CGR (eds) (2010) Northern Bald Ibis conservation and reintroduction workshop. In: Proceedings of 3rd meeting of international advisory group for Northern Bald Ibis (IAGNBI), Palmira, Syria, Nov 2009. ISBN: 978-1-905601-27-1

Bonier F, Martin PR, Moore IT, Wingfield JC (2009) Do baseline glucocorticoids predict fitness? Trends Ecol Evol 24:634-642. https ://doi.org/10.1016/j.tree.2009.04.013

Bortolotti GR, Marchant TA, Blas J, German T (2008) Corticosterone in feathers is a long-term, integrated measure of avian stress physiology. Funct Ecol 22:494-500. https://doi.org/10.111 $1 / \mathrm{j}$.1365-2435.2008.01387.x

Bortolotti GR, Marchant T, Blas J, Cabezas S (2009) Tracking stress: localisation, deposition and stability of corticosterone in feathers. J Exp Biol 212:1477-1482. https://doi.org/10.1242/jeb.022152

Burnham KP, Anderson DR (2002) Model selection and multimodel inference, 2nd edn. Springer, New York

Carbajal A, Tallo-Parra O, Sabes-Alsina M, Mular I, Lopez-Bejar M (2014) Feather corticosterone evaluated by ELISA in broilers: a potential tool to evaluate broiler welfare. Poult Sci 93:1-3

Cockrem JF (2013) Individual variation in glucocorticoid stress responses in animals. Gen Comp Endocrinol 181:45-58. https:// doi.org/10.1016/j.ygcen.2012.11.025

Cockrem JF, Silverin B (2002) Variation within and between birds in corticosterone responses of great tits (Parus major). Gen Comp Endocrinol 125:197-206. https://doi.org/10.1006/gcen.2001.7750

Cramp S (1998) The complete birds of the Western Palearctic on CDROM. Oxford University Press, Oxford

Crossin GT, Phillips RA, Lattin CR, Romero LM, Williams TD (2013) Corticosterone mediated costs of reproduction link current to future breeding. Gen Comp Endocrinol 193:112-120. https://doi. org/10.1016/j.ygcen.2013.07.011 
Cyr NE, Romero ML (2007) Chronic stress in free-living European starlings reduces corticosterone concentrations and reproductive success. Gen Comp Endocrinol 151:82-89. https://doi. org/10.1016/j.ygcen.2006.12.003

del Hoyo J, Elliott A, Sargatel J (1992) Handbook of the birds of the world. Volume 1: ostrich to ducks. Lynz Edicions, Barcelona

Dorn S, Wascher CAF, Möstl E, Kotrschal K (2014) Ambient temperature and air pressure modulate hormones and behaviour in Greylag geese (Anser anser) and Northern Bald Ibis (Geronticus eremita). Behav Process 108:27-35. https://doi.org/10.1016/j. beproc.2014.08.026

Fairhurst GD, Marchant TA, Soos C, Machin KL, Clark RG (2013) Experimental relationships between levels of corticosterone in plasma and feathers in a free-living bird. J Exp Biol 216:40714081. https://doi.org/10.1242/jeb.091280

Fairhurst GD, Bond AL, Hobson KA, Ronconi RA (2015) Featherbased measures of stable isotopes and corticosterone reveal a relationship between trophic position and physiology in a pelagic seabird over a 153-year period. Ibis (London 1859) 157:273-283. https://doi.org/10.1111/ibi.12232

Fairhurst GD, Champoux L, Hobson KA, Rail JF, Verreault J, Guillemette M, Montevecchi WA, Brousseau P, Soos C (2017) Feather corticosterone during non-breeding correlates with multiple measures of physiology during subsequent breeding in a migratory seabird. Comp Biochem Physiol Part A Mol Integr Physiol 208:1-13. https://doi.org/10.1016/j.cbpa.2017.02.024

Gill F (2007) Feathers. In: Gill F (ed) Ornithology, 3rd edn. W.H. Freemand and Company, New York, pp 79-113

Hardy J, Crick H, Wernham C, Riley H, Etheridge B, Thompson D (2006) Feathers. In: Hardy J (ed) Raptors: a field guide for surveys and monitoring. The Stationery Office, Edinburgh, pp 243-280

Harms NJ, Legagneux P, Gilchrist HG, Bety J, Love OP, Forbes MR, Bortolotti GR, Soos C (2015) Feather corticosterone reveals effect of moulting conditions in the autumn on subsequent reproductive output and survival in an Arctic migratory bird. Proc R Soc B Biol Sci 282:20142085. https://doi.org/10.1098/rspb.2014.2085

Harris CM, Madliger CL, Love OP (2017) An evaluation of feather corticosterone as a biomarker of fitness and an ecologically relevant stressor during breeding in the wild. Oecologia. https://doi. org/10.1007/s0042-017-3836-1

Jenni L, Jenni-Eiermann S, Spina F, Schwabl H (2000) Regulation of protein breakdown and adrenocortical response to stress in birds during migratory flight. Am J Physiol Regul Integr Comp Physiol 278:R1182-R1189

Jenni-Eiermann S, Helfenstein F, Vallat A, Glauser G, Jenni L (2015) Corticosterone: effects on feather quality and deposition into feathers. Methods Ecol Evol 6:237-246. https://doi. org/10.1111/2041-210X.12314

Johns DW, Marchant TA, Fairgurst GD, Speakman JR, Clark RG (2018) Biomarker of burden: feather corticosterone reflects energetic expenditure and allostatic overload in captive waterfowl. Funct Ecol 32:345-357. https://doi.org/10.1111/1365-2435.12988

Koren L, Nakagawa S, Burke T, Soma KK, Wynne-Edwards KE, Geffen E (2012) Non-breeding feather concentrations of testosterone, corticosterone and cortisol are associated with subsequent survival in wild house sparrows. Proc Biol Sci 279:15601566. https://doi.org/10.1098/rspb.2011.2062

Lattin CR, Reed JM, DesRochers DW, Romero LM (2011) Elevated corticosterone in feathers correlates with corticosterone-induced decreased feather quality: a validation study. J Avian Biol 42:247-252. https://doi.org/10.1111/j.1600-048X.2010.05310.x

Legagneux P, Harms NJ, Gauthier G, Chastel O, Gilchrist HG, Bortolotti G, Bêty J, Soos C (2013) Does feather corticosterone reflect individual quality or external stress in arctic-nesting migratory birds? PLoS ONE 8:e82644. https://doi.org/10.1371/ journal.pone.0082644
López-Jiménez L, Blas J, Tanferna A, Cabezas S, Marchant T, Hiraldo F, Fabrizio S (2016) Lifetime variation in feather corticosterone levels in a long-lived raptor. Oecologia. https://doi. org/10.1007/s00442-016-3708-0

Love OP, Shutt LJ, Silfies JS, Bird DM (2003) Repeated restraint and sampling results in reduced corticosterone levels in developing and adult captive American kestrels (Falco sparwerius). Physiol Biochem Zool 76(3):753-761

Lynn SE, Prince LE, Phillips MM (2010) A single exposure to an acute stressor has lasting consequences for the hypothalamopituitary-adrenal response to stress in free-living birds. Gen Comp Endocrinol 165:337-344. https://doi.org/10.1016/j.ygcen .2009 .07 .018

Mccallister J, Smith TE (1996) Validation of non-invasive cortisol enzyme-immunoassays in Callitrichid primates. In: 3rd Annual symposium on zoo research

Monclús L, Carbajal A, Tallo-Parra O, Sabés-Alsina M, Darwich L, Molina-López RA, Lopez-Bejar M (2017) Relationship between feather corticosterone and subsequent health status and survival in wild Eurasian Sparrowhawk. J Ornithol 158:773-783. https:// doi.org/10.1007/s10336-016-1424-5

Monclús L, Lopez-Bejar M, De la Puente J, Covaci A, Jaspers VLB (2019) Can variability in corticosterone levels be related to POPs and OPEs in feathers from nestling cinereous vultures (Aegypius monachus)? Sci Total Environ 650:184-192. https://doi. org/10.1016/j.scitotenv.2018.08.188

Möstl E, Rettenbacher S, Palme R (2005) Measurement of corticosterone metabolites in birds' droppings: an analytical approach. Ann N Y Acad Sci 1046:17-34. https://doi.org/10.1196/annal s. 1343.004

Müller C, Jenni-Eiermann S, Blondel J, Perret P, Caro SP, Lambrechts MM, Jenni L (2007) Circulating corticosterone levels in breeding blue tits Parus caeruleus differ between island and mainland populations and between habitats. Gen Comp Endocrinol 154:128-136. https://doi.org/10.1016/j.ygcen.2007.05.031

Nakagawa S, Schielzeth H (2010) Repeatability for Gaussian and nonGaussian data: a practical guide for biologists. Biol Rev 85:935956. https://doi.org/10.1111/j.1469-185X.2010.00141.x

Ouyang JQ, Sharp PJ, Dawson A, Quetting M, Hau M (2011) Hormone levels predict individual differences in reproductive success in a passerine bird. Proc R Soc B Biol Sci 278:2537-2545. https://doi. org/10.1098/rspb.2010.2490

Patterson AGL, Kitaysky AS, Lyons DE, Roby DD (2015) Nutritional stress affects corticosterone deposition in feathers of Caspian tern chicks. J Avian Biol 46:18-24. https://doi.org/10.1111/jav.00397

Pérez C, Granadeiro JP, Dias MP, Catry P (2016) Sex and migratory strategy influence corticosterone levels in winter-grown feathers, with positive breeding effects in a migratory pelagic seabird. Oecologia 181:1025-1033. https://doi.org/10.1007/s0044 2-016-3625-2

Puehringer-Sturmayr V, Wascher CAF, Loretto MC, Palme R, Stoewe M, Kotrschal K, Frigerio D (2018) Seasonal differences of corticosterone metabolite concentrations and parasite burden in Northern Bald Ibis (Geronticus eremita): the role of affilitative interactions. PLoS ONE 13(1):e0191441. https://doi.org/10.1371/ journal.pone. 0191441

Quevedo M (2009) Update report of Proyecto Eremita, March 2010. In: Boehm C, Bowden CGR (eds) Northern Bald Ibis conservation and reintroduction workshop. Proceedings of 3rd meeting of international advisory group for Northern Bald Ibis (IAGNBI), Palmira, Syria, Nov 2009. ISBN: 978-1-905601-27-1

R Core Team (2015) R. a language and environment for statistical computing. R Foundation for Statistical Computing, Vienna

Ramos R, Llabrés V, Monclús L, Lopez-Bejar M, Gonzalez-Solis R (2018) Costs of breeding are rapidly buffered and do not affect 
migratory behavior in a long-lived bird species. Ecology 99:20102024. https://doi.org/10.1003/ecy.2435

Rohwer S, Ricklefs RE, Rohwer VG, Copple MM (2009) Allometry of the duration of flight feather molt in birds. PLoS Biol 7(6):e1000132. https://doi.org/10.1371/journal.pbio.1000132

Romero LM, Fairhurst GD (2016) Measuring corticosterone in feathers: strengths, limitations, and suggestions for the future. Comp Biochem Physiol Part A Mol Integr Physiol 202:112-122. https ://doi.org/10.1016/j.cbpa.2016.05.002

Romero LM, Dickens MJ, Cyr NE (2009) The reactive scope model-a new model integrating homeostasis, allostasis, and stress. Horm Behav 55:375-389. https://doi.org/10.1016/j.yhbeh.2008.12.009

Sergio F, Blas J, Blanco G, Tanferna A, López L, Lemus JA, Hiraldo F (2011) Raptor nest decorations are a reliable threat against conspecifics. Science 331:327-330. https://doi.org/10.1126/scien ce. 1199422

Serra G, Lindsell JA, Fritz J, Bowden CGR, Bruschini C, Welch G, Tavares J, Wondafrash M (2015) Accounting for the low survival of the critically endangered Northern Bald Ibis Geronticus eremita on a major migratory flyway. Oryx 46(2):1-9. https://doi. org/10.1017/S0030605313000665

Sink TD, Lochmann RT, Fecteau KA (2008) Validation, use, and disadvantages of enzyme-linked immunosorbent assay kits for detection of cortisol in channel catfish, largemouth bass, red pacu, and golden shiners. Fish Physiol Biochem 34:95-101. https://doi. org/10.1007/s10695-007-9150-9

Sorato E, Kotrschal K (2006) Hormonal and behavioural symmetries between the sexes in the Northern Bald Ibis. Gen Comp
Endocrinol 146:265-274. https://doi.org/10.1016/j.ygcen .2005.11.020

Strong RJ, Pereira MG, Shore RF, Henrys PA, Pottinger TG (2015) Feather corticosterone content in predatory birds in relation to body condition and hepatic metal concentration. Gen Comp Endocrinol 214:47-55. https://doi.org/10.1016/j.ygcen.2015.03.002

Tallo-Parra O, Lopez-Bejar M, Carbajal A, Monclús L, Manteca X, Devant M (2016) Acute ACTH-induced elevations of circulating cortisol do not affect hair cortisol concentrations in calves. Gen Comp Endocrinol 240:138-142. https://doi.org/10.1016/j.ygcen .2016 .10 .007

Will AP, Suzuki Y, Elliott KH, Hatch SA, Watanuki Y, Kitaysky AS (2014) Feather corticosterone reveals developmental stress in seabirds. J Exp Biol 217:2371-2376. https://doi.org/10.1242/ jeb.098533

Wingfield JC, Sapolsky RM (2003) Reproduction and resistance to stress: when and how. J Neuroendocrinol 15:711-724. https://doi. org/10.1046/j.1365-2826.2003.01033.x

Wingfield JC, Maney DL, Breuner CW, Jacobs JD, Ramenofsky M, Richardson RD (1998) Ecological bases of hormone-behavior interactions : the "emergency life history stage". Am Zool 38:191-206. https://doi.org/10.1093/icb/38.1.191

Publisher's Note Springer Nature remains neutral with regard to jurisdictional claims in published maps and institutional affiliations.

\section{Affiliations}

\section{Laura Monclús $^{1,4}\left[\right.$ O Oriol Tallo-Parra ${ }^{2} \cdot$ Anais Carbajal $^{1} \cdot$ Miguel Angel Quevedo $^{3} \cdot$ Manel Lopez-Bejar $^{1}$}

1 Department of Animal Health and Anatomy, Faculty of Veterinary, Universitat Autònoma de Barcelona (UAB), 08193 Bellaterra, Spain

2 Department of Animal and Food Science, Faculty of Veterinary, Universitat Autònoma de Barcelona (UAB), 08193 Bellaterra, Spain
3 Zoobotanico de Jerez, c/ Taxdirt s/n, Jerez de la Frontera, 11404 Cádiz, Spain

4 Present Address: Department of Biology, Faculty of Natural Science, Norwegian University of Science and Technology (NTNU), 7491 Trondheim, Norway 